\title{
Sedimentary Oxygen Demand and Orthophosphate Release: Sustaining Eutrophication in a Tributary of the Chesapeake Bay
}

\author{
Tiara Nydia Moore ${ }^{1,2, *}$, Benjamin Elias Cuker ${ }^{1}$ \\ ${ }^{1}$ Department of Marine and Environmental Science, Hampton University, Hampton, United States of America \\ ${ }^{2}$ Ecology and Evolutionary Biology Department, University of California, Los Angeles, United States of America
}

\section{Email address:}

tiaranmoore $a$ gmail.com (T. N. Moore), benjamin.cuker $a$ hamptonu.edu (B. E. Cuker)

${ }^{*}$ Corresponding author

\section{To cite this article:}

Tiara Nydia Moore, Benjamin Elias Cuker. Sedimentary Oxygen Demand and Orthophosphate Release: Sustaining Eutrophication in a Tributary of the Chesapeake Bay. Journal of Water Resources and Ocean Science. Vol. 7, No. 3, 2018, pp. 42-48. doi: 10.11648/j.wros.20180703.13

Received: August 2, 2018; Accepted: September 4, 2018; Published: September 28, 2018

\begin{abstract}
Beginning in the mid 20th Century the Chesapeake Bay began to show the first signs of eutrophication, with seasonal depletion of free oxygen in bottom waters (hypoxia). Eutrophication is driven largely by external loading of phosphorus $(\mathrm{P})$ and nitrogen $(\mathrm{N})$. These nutrients maintain high levels of phytoplankton productivity and subsequent transfer of fixed carbon to the sediments. That carbon fuels heterotrophs that uptake free oxygen in the bottom waters at a faster rate than it can be replenished during seasonal stratification, resulting in periods of persistent hypoxia and anoxia. Aerobic and anaerobic decomposition of the settled plankton and detritus drives the release of remineralized nutrients such as orthophosphate (P). Episodic and seasonal mixing events transport the $\mathrm{N}$ and $\mathrm{P}$ to better illuminated surface waters where it supports blooms of phytoplankton, which will settle and continue the positive feedback loop of eutrophication. To better understand the role of sediments in the ongoing stress caused by eutrophication in the Chesapeake Bay we incubated sediment cores at temperatures to model an in situ seasonal cycle. We measured oxygen concentrations and P levels to estimate the release of orthophosphate to the overlying waters under various oxygen conditions. During oxic conditions the net flux of orthophosphate was from the water column into the sediments. Anoxia drove P flux from the sediments back to the water column. These results indicate internal P loading during periods of anoxia by the sediments to the water column may lead to continued eutrophication.
\end{abstract}

Keywords: Eutrophication, Chesapeake Bay, Multiple Stressors, Hypoxia, Sediment

\section{Introduction}

Anthropogenic eutrophication of lakes, estuaries, and coastal waters is a difficult process to reverse [1-2]. It is typically first established by excessive loading of a combination of inorganic nutrients $(\mathrm{N} \& \mathrm{P})$ and organic matter [3]. The organic pollution fuels blooms of phytoplankton (algae). Depending on the hydrodynamics of the system, the subsequent microbial oxygen demand is apportioned between the water column and the underlying sediments (Sediment Oxygen Demand or SOD) [4-5]. The microbial degradation of organic matter also remineralizes $\mathrm{N}$ and $\mathrm{P}$ [6-8]. That newly released $\mathrm{N}$ and $\mathrm{P}$ from the decaying organic matter, along with $\mathrm{N}$ and $\mathrm{P}$ from the watershed promote blooms of phytoplankton [8-9]. When those algae die and sink, it adds to the biological oxygen demand of the bottom waters and sediments. As with the organic matter washing in from the watershed, the settled algae degrade and release $\mathrm{N}$ and $\mathrm{P}$. Circulation of these regenerated nutrients to sufficiently illuminated surface waters stimulates another round of excessive phytoplankton growth [4, 10]. This positive-feedback loop is what makes the reversal of eutrophication so difficult $[1-2,11]$. Even after nutrient loading has been reduced, internal loading from the sediments can sustain algal blooms and the eutrophication syndrome [7, 11-12]. Suggesting that in these highly stressed ecosystems, "cascading" ecological phenomena can be 
observed [13-14].

Another major ecological stressor is hypoxia in coastal systems, which has been increasing since the early 1970's, especially in areas such as the northern Gulf of Mexico (NGM) [15-17]. Although the Chesapeake Bay's hypoxic zones are not as large as the NGM's, their formation is evident in many tributaries [18] This eutrophication-driven hypoxia is intensified by summer stratification as oxygen supplies are insufficient to compensate for the influx of new depositing organic material and older sediment stores $[2,19$ 20]. Yet another example of how one stressor, eutrophication, can lead to another stressor, hypoxia, in a system.

The algal blooms and hypoxia associated with eutrophication in temperate estuaries occur seasonally [17]. During spring and summer, the surface layer warms, resulting in reduced density of the water [12, 19]. This intensifies stratification, particularly in salt-wedge type estuaries, such as the Chesapeake Bay [11]. The fresher and less dense riverine flow floats atop of the saltier marine layer. The two layers are separated by a sharp density gradient (pycnoline) that inhibits mixing of the two layers, but permits the passage of sinking detritus, including dead and dying phytoplankton [19, 21-22]. Suggesting that the major effects of these cascading events would occur in the summer when the Bay is stratified where higher incidences of eutrophication and hypoxia have been observed [4, 22-23].

The purpose of this research is to examine the varying stressors that occur over a seasonal cycle in a tributary of the Chesapeake Bay. With the data, we will show that eutrophic conditions can be maintained during periods of hypoxia, or even caused by hypoxia. Our goal is to connect human induced environmental conditions (nutrient pollution) to subsequent ecological stressors (eutrophication \& hypoxia) experienced in the Bay. As well as to gauge the importance of SOD to the general oxygen budget, while also estimating the potential contribution of $\mathrm{P}$ released from the sediments. To address these issues, we conducted experiments that simulated an annual seasonal temperature cycle in the Bay, while measuring oxygen and $\mathrm{P}$ concentration in sediment cores. These data show that the cascading effects one stressor may have on another is a major ecological concern in this anthropogenic era.

\section{Materials and Methods}

\subsection{Study Area}

The Chesapeake Bay is the largest estuary in the United States (322 km long). The Bay drains areas in New York, Pennsylvania, Delaware, Maryland, Virginia, West Virginia, and the District of Columbia [21]. The watershed is home to more than 18 million people with a land area-to-water surface area ratio of 14:1. Increasing human population growth and related land development in the watershed since 1950 (10.4 million) has driven pollution of the Bay and degradation of water quality $[2,4,17]$.

This study was conducted in the Hampton River, a tributary of the Chesapeake Bay near Hampton University in Hampton, Virginia. The samples were collected from sites across the tributary which included Jones Creek, Sunset Creek, and Hampton River (Figure 1, Table 1). The Hampton River is $5.2 \mathrm{~km}$ long and is contained entirely in the city of Hampton, Virginia. The river empties into the mouth of Hampton Roads (large harbor) which then empties into the southern end of the Chesapeake Bay. The Hampton River is connected to two tidal guts, Jones Creek and Sunset Creek, all of which have variable depths ranging from 1.9 to $4.6 \mathrm{~m}$. As noted in most Bay tributaries $[9,19,23]$, this system would be expected to experience seasonal eutrophication and hypoxia.

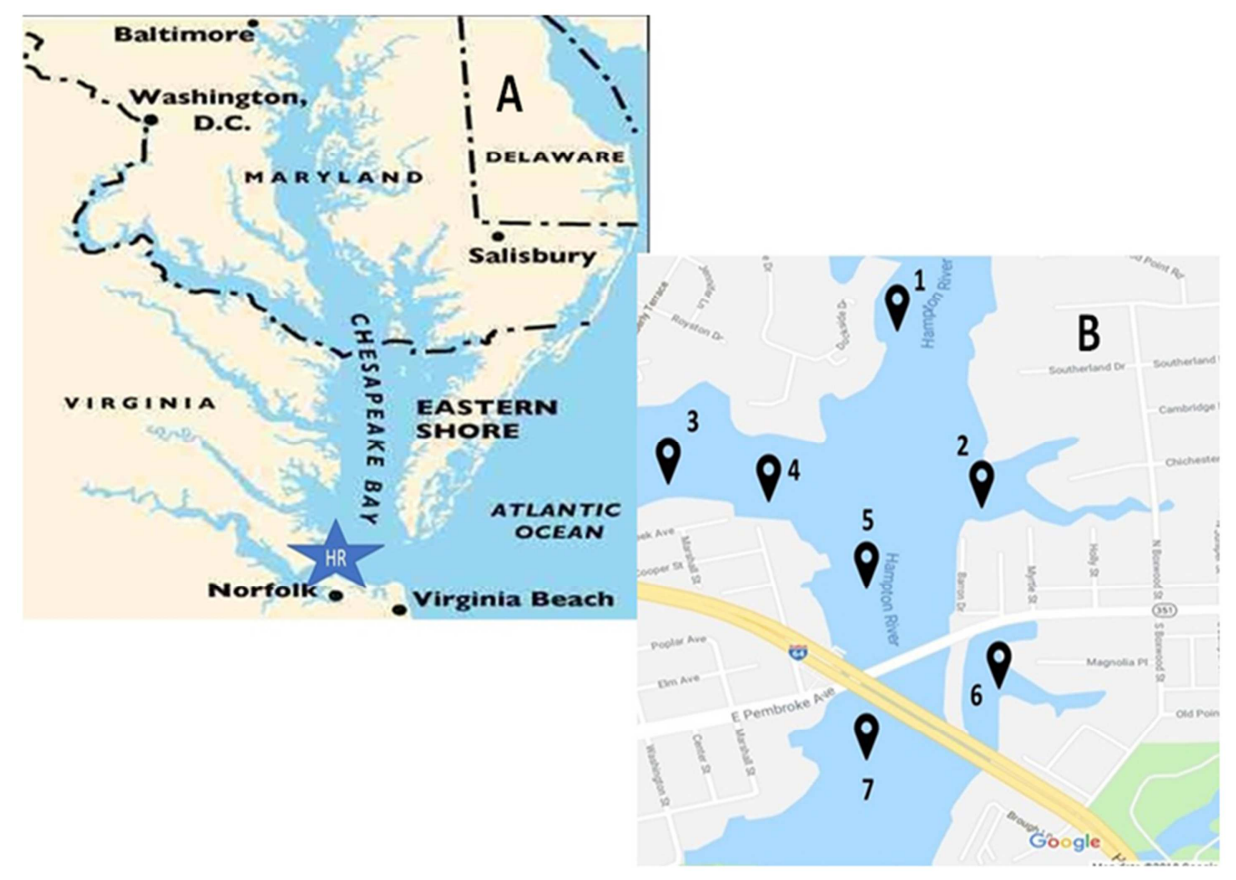

Figure 1. A) Map of Chesapeake Bay, star indicates Hampton River system. B) Collection sites. 
Table 1. Hampton River system collection sites GPS locations.

\begin{tabular}{|c|c|c|c|}
\hline Station & Location & Latitude & Longitude \\
\hline 1 & Jones Creek & $\mathrm{N} 37^{\circ} 01^{\prime} .036$ & W076 $20^{\prime} .329$ \\
\hline 2 & Jones Creek & $\mathrm{N} 37^{\circ} 01^{\prime} .020$ & W076 $20^{\prime} .150$ \\
\hline 3 & Sunset Creek & $\mathrm{N} 37^{\circ} 01^{\prime} .050$ & W076 $20^{\prime} .703$ \\
\hline 4 & Sunset Creek & $\mathrm{N} 37^{\circ} 01^{\prime} .033$ & W076 $21^{\prime} .025$ \\
\hline 5 & Hampton River & $\mathrm{N} 37^{\circ} 01^{\prime} .266$ & W076 $20^{\prime} .569$ \\
\hline 6 & Hampton River & $\mathrm{N} 37^{\circ} 01^{\prime} .346$ & W076 $20^{\prime} .618$ \\
\hline 7 & Hampton River & $\mathrm{N} 37^{\circ} 01^{\prime} .592$ & W076 $20^{\prime} .318$ \\
\hline
\end{tabular}

\subsection{Sample Collection}

Hand-core samples were collected by diving, at 7 sites in Jones Creek, the Sunset Creek, and the Hampton River in June of 2012. These sites were chosen to represent and characterize the entire Hampton Roads tributary. Core samples were collected using $55 \mathrm{~cm}$ long, $4.75 \mathrm{~cm}$ internal diameter clear plastic core tubes. Each tube was graduated in $1 \mathrm{~cm}$ increments along the side before collection to ensure accurate measurements. Each core collected had $35 \mathrm{~cm}$ of water overlying $20 \mathrm{~cm}$ of sediment. At each station, two duplicate sediment samples were taken along with a core tube used solely to capture water from just above the sediments to measure water column respiration. The data for the 3 cores were pooled and each site was used as a replicate in the statistical analysis (t-test). Permission to collect was provided by Hampton University, no endangered or protected species were involved in this research.

At each collection site, the salinity (19.1 - 19.8 PPT), temperature (27.3 - 27.8), and dissolved oxygen (65.3 $84.9 \%$ ) were measured from the bottom water which was about $1 \mathrm{~m}$ above the sediment. A model number 85-10 FT Yellow Springs Instrument (YSI) oxygen meter was used for each measurement. For each station, the latitude and longitude were recorded using Garmin GPS \#76Cx (Table 1), and a Raymarine meter was used to determine water depth (2.2 - $4.6 \mathrm{~m})$. The sediment throughout the tributary appeared oxygen rich as they were brown in color, and a grain size analysis indicated 'fine' as the dominant sediment type.

\subsection{Experimental Procedures}

Using the same YSI meter, each core was measured separately for temperature, salinity, and dissolved oxygen in the laboratory. The YSI probe was inserted into each sediment core tube to a level $(10 \mathrm{~cm})$ well above the sediment-water interface, to prevent resuspension of sediments, and stirred continuously until the reading stabilized. This procedure was meant to simulate the mixing of water overlying natural sediments caused by the semidiurnal tidal cycle. The mixing disrupted any potential micro-scale oxycline expected to develop in the quiescent confines of the core tubes.

Once the measurements were completed, the cores were then capped and incubated without light at $28^{\circ} \mathrm{C}$ in a Thermo Scientific 3759 Precision Incubator. The cores were then checked hourly for temperature, and dissolved oxygen. Once the samples reached anoxic levels, they were left in the incubator for a resting period of one week. After the weeklong resting period, a $30 \mathrm{ml}$ water sample was removed for orthophosphate analysis using EPA method 365.2. The samples were then set-up for aeration using air pumps, aquarium tubing, and t-valves. To complete aeration, a second set of sample caps were modified with two small holes. One hole was used to insert the aquarium tube $1 \mathrm{~cm}$ below the surface of the water, and the other hole was used as an air hole to permit the slightly pressurized air to exit. Cores were aerated for one hour twice daily for one week in order to make sure the microbial community was no longer oxygen starved and consuming oxygen at a stable rate. After the oxygen measurements stabilized at $100 \%$ another $30 \mathrm{ml}$ subsample of water was removed for orthophosphate analysis. After each aeration, the cores were incubated at $22^{\circ} \mathrm{C}$, and another $30 \mathrm{ml}$ subsample of water was removed for orthophosphate analysis. The core samples were then checked for temperature, and dissolved oxygen. Once the samples reached anoxic levels, they were immediately set up for aeration and aerated twice daily for one week. This was repeated for 15,9 and $4{ }^{\circ} \mathrm{C}$ (annual temperature cycle experienced by the Bay). The same cores were used in order to replicate a natural seasonal oxygen cycle experienced by the sediment.

\subsection{Calculations and Statistics}

All sediment oxygen demand (SOD) calculations were corrected for the metabolism of the water column by subtracting the oxygen demand determined for the wateronly core (WCOD) from the SOD found for each corresponding sediment core. The change in oxygen concentrations over the first 24 hours after halting oxygenation were used to establish the SOD for each temperature. The oxygen concentration after the first 24 hours was subtracted from the initial oxygen concentration in order estimate uptake of dissolved oxygen. Next, the volume of water (liters) was multiplied by the concentration of oxygen $\left(\mathrm{mg} \mathrm{l}^{-1}\right)$; the product was then divided by the measured area of the sediment within the tube (Table 2).

Table 2. Formulas used to calculate 1) Change in SOD, 2) SOD per day, 3) Annual SOD, 4) PO4 release.

\begin{tabular}{|c|c|c|c|}
\hline Calculation & Formula & Variable 1 & Variable 2 \\
\hline$\Delta \mathrm{SOD}=$ & $\mathrm{X}_{1} \mathrm{O}_{2} \mathrm{mg} \mathrm{l}^{-1}-\mathrm{X}_{2} \mathrm{O}_{2} \mathrm{mg} \mathrm{l}^{-1}$ & $\mathrm{X}_{1} \mathrm{O}_{2} \mathrm{mg} \mathrm{l}^{-1}=\mathrm{SOD} \mathrm{mg} \mathrm{l^{-1 }}$ & $\mathrm{X}_{2} \mathrm{O}_{2} \mathrm{mg} \mathrm{l}^{-1}=\mathrm{mg} \mathrm{l}^{-1}$ from water only core \\
\hline $\mathrm{O}_{2} \mathrm{~g} \mathrm{~m}^{-2} \mathrm{~d}^{-1}=$ & 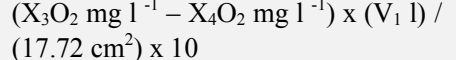 & 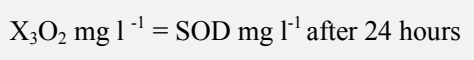 & $\mathrm{X}_{4} \mathrm{O}_{2} \mathrm{mg} \mathrm{l}^{-1}=$ initial SOD $\mathrm{mg} \mathrm{l}^{-1}$ \\
\hline ASOD $\mathrm{g} \mathrm{m}^{-2}=$ & $\left(\right.$ SOD $\left.\operatorname{g~m}^{-2} \mathrm{~d}^{-1}\right) \mathrm{x}$ (days) & SOD $\mathrm{g} \mathrm{m}^{-2} \mathrm{~d}^{-1}=$ mean SOD in $\mathrm{g} \mathrm{m}^{-2} \mathrm{~d}^{-1}$ & \\
\hline$\Delta \mathrm{PO}_{4}=$ & $\mathrm{X}_{1} \mathrm{PO}_{4} \mathrm{mgl}^{-1}-\mathrm{X}_{2} \mathrm{PO}_{4} \mathrm{mg} \mathrm{l}^{-1}$ & $\mathrm{X}_{1} \mathrm{PO}_{4} \mathrm{mgl}^{-1}=\mathrm{PO}_{4} \mathrm{mgl}^{-1}$ & $\begin{array}{l}\mathrm{X}_{2} \mathrm{PO}_{4} \mathrm{mg} \mathrm{l}^{-1}=\mathrm{PO}_{4} \mathrm{mg} \mathrm{l}^{-1} \text { from water only } \\
\text { core }\end{array}$ \\
\hline
\end{tabular}


In order to estimate the apportionment of SOD and WCOD over the annual cycle, data from the LE 5.4 Long Term Monitoring Station were used to approximate the different seasonal water temperatures. We assumed that the annual cycle consisted of: $28^{\circ} \mathrm{C}$ - summer (62 days), $22^{\circ} \mathrm{C}$ - early summer (91 days), $15^{\circ} \mathrm{C}$ - spring/ fall (61 days), $9^{\circ} \mathrm{C}$ - late fall/ early spring ( 89 days), and $4^{\circ} \mathrm{C}$ - winter (62 days). These data allowed for the annual percentage of SOD and WCOD to be determined at each temperature for the Hampton River Tributary (Table 2).

Orthophosphate release was corrected for metabolism of the water column by subtracting the orthophosphate concentration determined for the water-only core from the orthophosphate concentration determined for each corresponding sediment core. The first 24 hours was also used to establish the release rate of orthophosphate (Table 2).

All raw data were input and calculated in Excel. An
ANOVA was conducted followed by a Tukey HSD test to distinguish significance between SOD and temperature. A paired t-test was used to identify the relationship between oxygen and $\mathrm{P}$ release. All tests and all figures were prepared using RStudio Version 1.0.143. The cores from each site were pooled and each location was used as a replicate $(n=7)$ for these analyses.

\section{Results}

As expected SOD generally tracked temperature, with the lowest estimates associated with the lowest temperatures ranging from $0.11-0.94 \mathrm{~g} \mathrm{~m}^{2} \mathrm{~h}^{-1}$. However, SOD was consistently higher at $22 \mathrm{C}$ than at $28 \mathrm{C}$ (Figure 2). ANOVA analysis shows temperature is a significant factor to sediment oxygen demand, and varies over the annual cycle (Table 3 ).

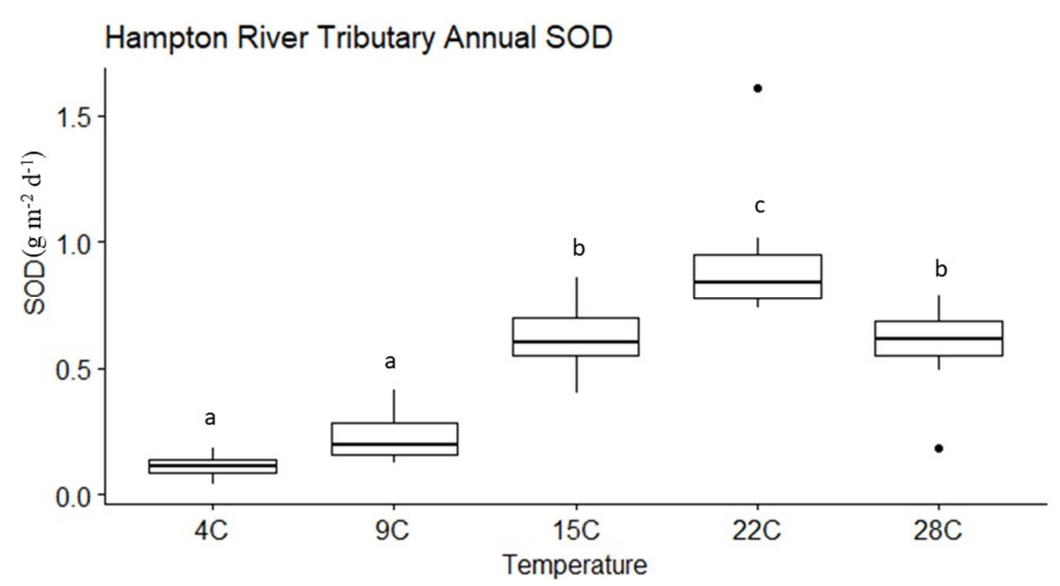

Figure 2. Annual SOD for the Hampton River Tributary plus Tukey HSD results. A) The colder temperatures (4C winter and 9 C early fall) had a similar effect on SOD. B) 15C (early spring) and 28 (late summer) had a similar effect on SOD. C) 22 (early summer) required the highest SOD, and was not similar to any of the other temperatures.

Table 3. ANOVA Table for annual SOD. All temperatures have a significant effect on SOD.

\begin{tabular}{llllll}
\hline & Df & Sum Sq. & Mean Sq. & F value & Pr(>F) \\
\hline temp & 4 & 3.132 & 0.7829 & 23.06 & $8.71 \mathrm{e}-09 * * *$ \\
Residuals & 30 & 1.019 & .0340 & & \\
Signif. codes & 0 ‘***, & $0.001^{* * *}$, & $0.01^{\circ *}, \cdot$, & 0.1 ', \\
\hline
\end{tabular}

All stations in the Hampton River tributary showed a similar pattern of SOD with regard to temperature. SOD for all of the stations peaked at $22^{\circ} \mathrm{C}$ which accounted for $46 \%$ of the total annual SOD. $20 \%$ of the annual oxygen demand occurred at $15^{\circ} \mathrm{C}$, and $19 \%$ at $28^{\circ} \mathrm{C}$. The SOD was the lowest during the 9 and $4{ }^{\circ} \mathrm{C}$ incubations being only $11 \%$ and $4 \%$ each of the annual budget. On an annual basis SOD is four times greater than the WCOD (Table 4). The SOD and WCOD were highest during the simulated early summer and lowest during the simulated winter.

Table 4. Sediment Oxygen Demand vs Water Column Oxygen Demand over an annual cycle. The percentage SOD is greater than WCOD was also calculated.

\begin{tabular}{llll}
\hline Temperature & Mean SOD $\left(\mathbf{g ~ O}^{2} \mathbf{~ m}^{-2} \mathbf{s e a s o n}^{-1}\right)$ & Mean WCOD $\left(\mathbf{g ~ O}^{2} \mathbf{~ m}^{-2}\right.$ season & \\
\hline $28^{\circ} \mathrm{C}$ & 35.96 & 13.64 & 45 \\
$22^{\circ} \mathrm{C}$ & 86.45 & 18.2 & 65 \\
$15^{\circ} \mathrm{C}$ & 37.82 & 3.66 & 82 \\
$9^{\circ} \mathrm{C}$ & 20.47 & 12.46 & 24 \\
$4^{\circ} \mathrm{C}$ & 6.82 & 0 & 100 \\
Annual Demand & $187.52 \mathrm{~g} \mathrm{O}^{2} \mathrm{~m}^{-2}$ & $47.96 \mathrm{~g} \mathrm{O}^{2} \mathrm{~m}^{-2}$ & 59 \\
\hline
\end{tabular}

The mean orthophosphate release for the Hampton River tributary after one week of anoxia was $78.28 \mu \mathrm{mol}$ P m2 h-1
(Figure 3). The mean orthophosphate release for the Hampton River tributary after one week of reaeration ranged 
was $18.22 \mu \mathrm{mol} \mathrm{P} \mathrm{m} 2 \mathrm{~h}-1$. Note that negative numbers indicate orthophosphate transport from the water column back into the sediment, while positive numbers indicate orthophosphate release from the sediment into the water column (Figure 3). A paired t-test identified the relationship between oxygen and phosphate flux to be significant, with the anoxic treatment having a greater release of $\mathrm{P}$ than the aerated treatment $(p=0.0005)$. The range of $P$ flux measured along the tributary is depicted in Figure 4.

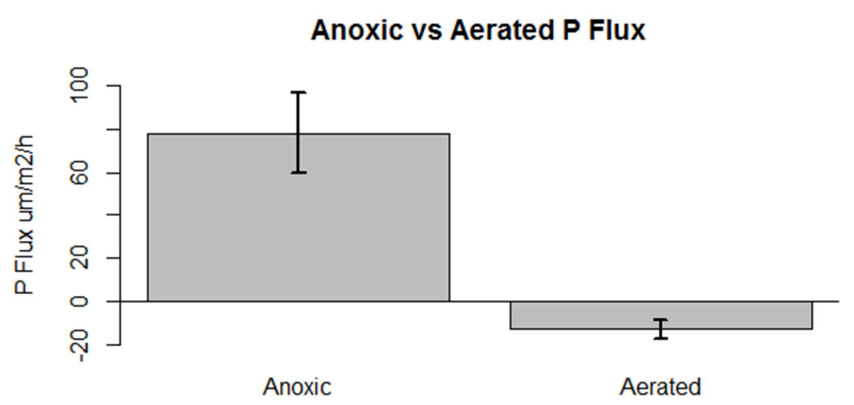

Figure 3. Anoxic vs. Aerated P flux. Mean P flux $+/-1$ standard error for the Hampton River Tributary. (-) indicates direction of flux.

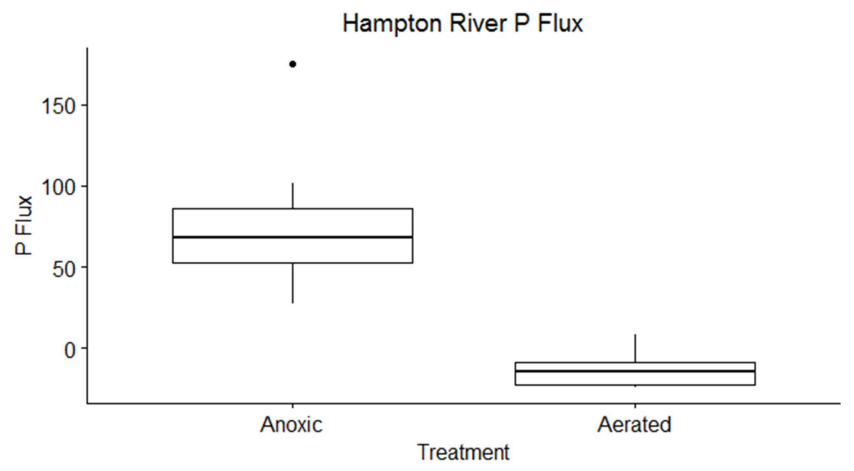

Figure 4. Hampton River P flux. Range of $P$ flux across the tributary under varying oxygen conditions.

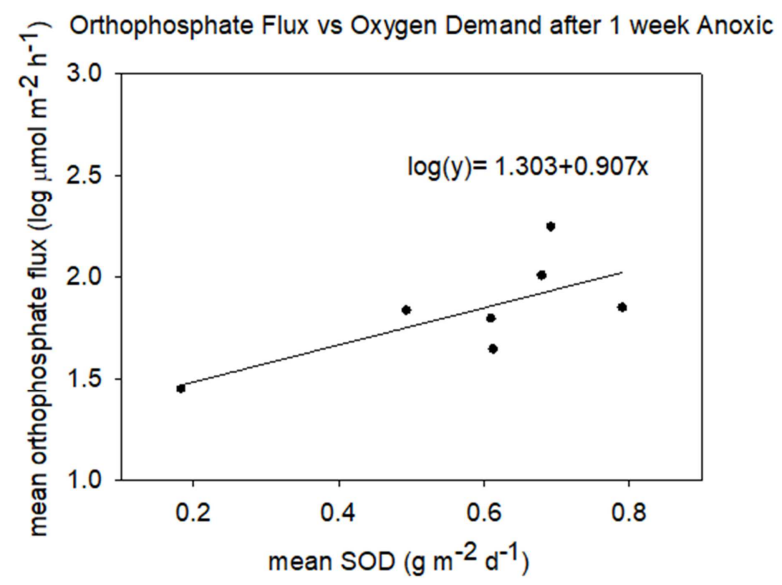

Figure 5. Orthophosphate release vs. sediment oxygen demand for the Hampton River Tributary after one week of anoxia.

The rate of $\mathrm{P}$ release from the sediments was proportional to the measured sediment oxygen demand. The relationship between SOD and the log of orthophosphate release after an anoxic period of one week appeared to be linear with a regression analysis that produced an $r^{2}$ value of 0.5001 (Figure 5).

\section{Discussion}

Our results imply that $\mathrm{P}$ release from the sediment in concert with high SOD may sustain eutrophication even without allocanthous nutrient loading. Other studies documented extensive P flux from sediments under anoxia, and this must be considered during restoration planning [12, 24 - 26]. Due to changes in the sediment biogeochemistry, we must consider the effects that may be caused under changing environmental conditions [5, 8]. In the Hampton River system about $46 \%$ of the annual SOD occurred during the $22^{\circ} \mathrm{C}$ incubation, which corresponds to late spring and early fall (Figure 2). It was initially expected that the highest SOD would occur during the $28^{\circ} \mathrm{C}$ incubation (summer); since metabolic rates generally increase in proportion to temperature. Although, in recent studies the formation of hypoxia is occurring earlier summer versus previous years late summer start [27]. The Chesapeake Bay monitoring program also found SOD's higher in May and June $\left(22^{\circ} \mathrm{C}\right)$ than that found in August $\left(28^{\circ} \mathrm{C}\right)$ [28]. This could be attributed to a shift in the microbial community at higher temperatures, and should be further addressed.

Under normoxia, orthophosphate binds to hydroxides of both iron (Fe) and manganese $(\mathrm{Mn})$ forming solid-phase substances that remain within the sediment [20, 29]. Under anoxia, Fe and Mn are reduced by anaerobic bacteria. This is mediated through sulfate reduction; where sulfate is used as a terminal electron acceptor. The now sulfate-rich water decreases the $\mathrm{pH}$ and causes a reducing environment. This drives release of orthophosphate from the sediment into the water column during anoxia [29]. A study analyzing oxygen data from the Bay over recent years concluded that "nutrient load reductions will lead to reduced hypoxic volumes" [18]. Another study in 2016 reported that their "model results suggest that nutrient loading is the main mechanism driving interannual hypoxia variability in Chesapeake Bay" [17]. More prevalently, Joshi et al. provided the first evidence that $\mathrm{P}$ cycling in the sediment is predominated by organic matter remineralization in the Bay sediments [26], which corresponds directly to what was found in the current study. Using isotope data, they were able to identify the source of $\mathrm{P}$ found in the sediment, and they concluded it was mostly authigenic P [26]. Also, in a recent review exploring oxygen trends in the Chesapeake Bay, hypoxia has been occurring for the past 80 years but has increased substantially in the last 10 years due to increased nutrient input which ends up remineralizing in the sediment [30]. Howarth et al, are calling the cycles of eutrophication and hypoxia biogeochemically coupled as one appears to consistently sustain and promote the other [7].

\section{Conclusion}

Our results show that for the Hampton River tributary in 
the early spring time, even before hypoxic events, the sediments demand 0.58 to $0.95 \mathrm{~g} \mathrm{O} 2 \mathrm{~m}-2 \mathrm{~d}-1$. From the calculated SOD, it is evident that the sediments are the primary source of oxygen consumption in the relatively shallow Hampton River system. This implies further that the high sediment oxygen demand can lead to hypoxic events and subsequent nutrient release. The subsequent nutrient release, at least for this system, appears to be high enough to sustain eutrophication with this additional source of $\mathrm{P}$ to the water column. As such, managers must understand that efforts to curtail nutrient pollution alone will not solve water quality problems in the short-term but are essential for the long-term health of the Chesapeake Bay. Managers must take in to account the internal recycling of $\mathrm{P}$ and other nutrients from the sediments when applying measures to decrease nutrient loading and subsequent eutrophication.

\section{Acknowledgements}

We want to thank all who helped contribute to this work; specifically: Ms. Camille Gaynus and Ms. Amanda Wise. Thanks also to the entire Marine and Environmental Science Department at Hampton University, VA, USA. Funding was provided by the Living Marine Resources Cooperative Science Center.

\section{References}

[1] D. Breitburg, "Effects of hypoxia, and the balance between hypoxia and enrichment, on coastal fishes and fisheries," Estuaries, vol. 25, no. 4 B, pp. 767-781, 2002.

[2] J. D. Hagy, W. R. Boynton, C. W. Keefe, and K. V. Wood, "Hypoxia in Chesapeake Bay, 1950-2001: Long-term change in relation to nutrient loading and river flow," Estuaries, vol. 27, no. 4, pp. 634-658, 2004.

[3] S. W. Nixon, "Coastal marine eutrophication: A definition, social causes, and future concerns," Ophelia, vol. 41, no. 1, pp. 199-219, 1995.

[4] C. C. F. and N. M. R., "Twenty - One - Year Simulation of Chesapeake Bay Water Quality Using the CE - QUAL - ICM Eutrophication Model," JAWRA J. Am. Water Resour. Assoc., vol. 49, no. 5, pp. 1119-1133, Sep. 2013.

[5] M. Huettel, P. Berg, and J. E. Kostka, "Benthic Exchange and Biogeochemical Cycling in Permeable Sediments," Ann. Rev. Mar. Sci., vol. 6, no. 1, pp. 23-51, 2014.

[6] J. E. Cloern, "Our evolving conceptual model of the coastal \reutrophication problem," Mar. Ecol. Prog. Ser., vol. 210, pp. 223-253, 2001.

[7] D. A. Smith and G. Matisoff, "Sediment Oxygen Demand in the Central Basin of Lake Erie," J. Great Lakes Res., vol. 34, no. 4, pp. 731-744, 2008.

[8] R. Howarth et al., "Coupled biogeochemical cycles: Eutrophication and hypoxia in temperate estuaries and coastal marine ecosystems," in Frontiers in Ecology and the Environment, 2011, vol. 9, no. 1, pp. 18-26.
[9] W. Boynton and W. Kemp, "Nutrient regeneration and oxygen consumption by sediments along an estuarine salinity gradient," Mar. Ecol. Prog. Ser., vol. 23, pp. 45-55, 1985.

[10] D. J. Conley, J. Carstensen, R. Vaquer-Sunyer, and C. M. Duarte, "Ecosystem thresholds with hypoxia," Hydrobiologia, vol. 629, no. 1, pp. 21-29, 2009.

[11] S. K. Sturdivant, R. J. Díaz, and G. R. Cutter, "Bioturbation in a declining oxygen environment, in situ observations from wormcam," PLoS One, vol. 7, no. 4, 2012.

[12] W. R. Boynton, M. A. C. Ceballos, E. M. Bailey, C. L. S. Hodgkins, J. L. Humphrey, and J. M. Testa, "Oxygen and Nutrient Exchanges at the Sediment-Water Interface: a Global Synthesis and Critique of Estuarine and Coastal Data," Estuaries and Coasts, vol. 41, no. 2, pp. 301-333, Mar. 2018.

[13] C. M. Crain, K. Kroeker, and B. S. Halpern, "Interactive and cumulative effects of multiple human stressors in marine systems," Ecol. Lett., vol. 11, no. 12, pp. 1304-1315, 2008.

[14] P. J. J., T. C. R., and M. C. D., "Reconceptualizing synergism and antagonism among multiple stressors," Ecol. Evol., vol. 5, no. 7, pp. 1538-1547, Mar. 2015.

[15] N. N. Rabalais et al., "Nutrient Changes in the Mississippi River and System Responses on the Adjacent Continental Shelf," Estuaries, vol. 19, no. 2, p. 386, 1996.

[16] D. Scavia, N. N. Rabalais, R. E. Turner, D. Justić, and W. J. Wiseman, "Predicting the response of Gulf of Mexico hypoxia to variations in Mississippi River nitrogen load," Limnol. Oceanogr., vol. 48, no. 3, pp. 951-956, 2003.

[17] M. Li et al., "What drives interannual variability of hypoxia in Chesapeake Bay: Climate forcing versus nutrient loading?," Geophys. Res. Lett., vol. 43, no. 5, pp. 2127-2134, 2016.

[18] J. M. Testa et al., "Quantifying the effects of nutrient loading on dissolved $\mathrm{O} 2$ cycling and hypoxia in Chesapeake Bay using a coupled hydrodynamic-biogeochemical model," J. Mar. Syst., vol. 139, pp. 139-158, 2014.

[19] R. J. Diaz, "Overview of Hypoxia around the World," J. Environ. Qual., vol. 30, no. 2, p. 275, 2001.

[20] W. C. Long and R. D. Seitz, "Hypoxia in chesapeake bay tributaries: Worsening effects on macrobenthic community structure in the York River," Estuaries and Coasts, vol. 32, no. 2, pp. 287-297, 2009.

[21] R. J. Diaz, G. R. Cutter, and D. M. Dauer, "A comparison of two methods for estimating the status of benthic habitat quality in the Virginia Chesapeake Bay," J. Exp. Mar. Bio. Ecol., vol. 285, pp. 371-381, 2003.

[22] H. S. Lim, R. J. Diaz, J. S. Hong, and L. C. Schaffner, "Hypoxia and benthic community recovery in Korean coastal waters," Mar. Pollut. Bull., vol. 52, no. 11, pp. 1517-1526, 2006.

[23] W. M. Kemp, J. M. Testa, D. J. Conley, D. Gilbert, and J. D. Hagy, "Temporal responses of coastal hypoxia to nutrient loading and physical controls," Biogeosciences, vol. 6, no. 12, pp. 2985-3008, 2009.

[24] W. Boynton, W. M. Kemp, C. G. Osborne, and V. S. Kennedy, "Nutrient fluxes across the sediment-water interface in the turbid zone of a coastal plain estuary," in Estuarine Perspectives, 1980, pp. 93-109. 
[25] V. Ruban and D. Demare, "Sediment phosphorus and internal phosphate flux in the hydroelectric reservoir of Bort-les-Orgues, France," Hydrobiologia, vol. 373/374, pp. 349-359, 1998.

[26] S. R. Joshi, R. K. Kukkadapu, D. J. Burdige, M. E. Bowden, D. L. Sparks, and D. P. Jaisi, "Organic matter remineralization predominates phosphorus cycling in the mid-bay sediments in the chesapeake bay," Environ. Sci. Technol., vol. 49, no. 10, pp. 5887-5896, 2015.

[27] J. Testa and W. Michael Kemp, Hypoxia-induced shifts in nitrogen and phosphorus cycling in Chesapeake Bay, vol. 57. 2012 .

[28] P. J. Tango and R. A. Batiuk, "Chesapeake Bay recovery and factors affecting trends: Long-term monitoring, indicators, and insights,” Reg. Stud. Mar. Sci., vol. 4, pp. 12-20, 2016.
[29] J. B. Percival and P. J. Lindsay, "Measurement of physical properties of sediments. In: Murdoch A, Azcue J, Mudroch P. Manual of physico-chemical analysis of aquatic sediments. Boca Raton: CRC Press, Inc: 1997. Pp. 7-38

[30] J. M. Testa et al., "Ecological Forecasting and the Science of Hypoxia in Chesapeake Bay," Bioscience, vol. 67, no. 7, pp. 614-626, 2017.

[31] R. A. Batiuk, D. L. Breitburg, R. J. Diaz, T. M. Cronin, D. H. Secor, and G. Thursby, "Derivation of habitat-specific dissolved oxygen criteria for Chesapeake Bay and its tidal tributaries,” J. Exp. Mar. Bio. Ecol., vol. 381, no. SUPPL., 2009. 